\title{
Fogedia giffeniana (Foged) Witkowski, Lange-Bertalot, Metzeltin \& Bafana a benthic diatom new to the Turkish Aegean Sea
}

\section{Ege Denizinden yeni bentik diyatom Fogedia giffeniana (Foged) Witkowski, Lange-Bertalot, Metzeltin \& Bafana}

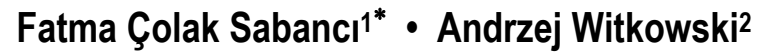

${ }^{1}$ Ege University, Faculty of Fisheries, Department of Hydrobiology, Bornova 35100, Izmir, Turkey 2Institute of Marine Sciences, University of Szczecin, Mickiewicza 18, PL-70-383 Szczecin, Poland *Corresponding author: sabancifatma@gmail.com

How to cite this paper:

Sabancı,C..F., Witkowski, A., 2014. Fogedia giffeniana (Foged) Witkowski, Lange-Bertalot, Metzeltin \& Bafana a benthic diatom new to the Turkish Aegean Sea. Ege J Fish Aqua Sci 31(3): 133-136. doi: 10.12714/egejfas.2014.31.3.03

\begin{abstract}
Özet: Bu çalışmada Homa lagünü’nden (Ege Denizi, Türkiye) toplanan materyalden bentik diyatom türü Fogedia giffeniana'nın varlığı rapor edilmiştir. Türler ışık mikroskopu altında incelenerek, türün morfolojik karakteristlikleri ayrıntılı olarak açıklanmıştır. Orijinal fotoğrafların yanında, ayrıca türün coğrafik dağıımı ve
\end{abstract} bulunduğu substratum hakkında bilgi verilmiştir.

Anahtar kelimeler: Fogedia, Morphometik data, Homa Lagünü, Doğu Akdeniz

Abstract: The study documents the occurrence of benthic diatom Fogedia giffeniana collected in the Homa lagoon (Aegean Sea, Turkey). Specimens were examined under the light microscope and morphological characteristics of this species were given in detail. Apart from the photo documentation, some information on the species geographical distribution patterns and the type of the substratum are also provided.

Keywords: Fogedia, Morphometric data, Homa Lagoon, Eastern Mediterranean

\section{INTRODUCTION}

Coastal lagoon ecosystems are a particular type of estuarine systems which varies from freshwater media to excessive salty water media. The present study is conducted in Homa Lagoon, where there was a wide spectrum of ecologically different biotopes and this allows the formation of marine, brackish water and fresh water to form in the region. The taxonomic composition of phytoplankton community in the study area was examined only once during the last ten years (Cirik et al., 1991) whereas benthic diatom surveys have been conducted recently (Çolak Sabancı 2010; 2011; 2012a, b; 2013). The studies on microphytobenthos are very limited in comparison to pelagic component, and especially the taxonomic literature on brackish water diatoms is quite scattered. The detailed description of the taxonomy, ecology and distribution of species obtained in this study will help both the correct species to be recognised for future studies and the development of a comprehensive diatom flora of the Aegean coast.
The genus of Fogedia was established towards the end of the 1990s based on the transfer of several taxa originally described as Navicula s.l. by e.g. Foged (1975) (cf. Witkowski et al., 1997; 2000). In Fogedia the most important characters allowing it to be separated from Navicula s.str. include the internal raphe slit being straight vs. strongly oblique in Navicula s.str. and the presence of short, simple apical external raphe endings instead of strongly hooked in the same side as in Navicula S.str., e.g., Cox (1979), Lange-Bertalot (2001), Witkowski et al. (2010). In addition, the valve face of most Fogedia species bears a lateral area differing from those observed either in Fallacia A. J. Stickle \& D. G. Mann in F. E. Round et al. (1990) or in Lyrella Karayeva (cf. Round et al., 1990; Witkowski et al., 1997).

\section{MATERIALS AND METHODS}

The study area is located in Gediz Delta region $\left(38^{\circ} 30^{\prime} \mathrm{N}\right.$, $\left.26^{\circ} 55^{\prime} \mathrm{E}\right)$. The samples originate from Izmir. Gediz Delta (20400 ha), which consists of fresh water and salt water 
marshes (5000 ha), bays and salt pans (3300 ha) and the lagoonary areas which form the typical Mediterranean delta ecosystem. The average rainfall and temperature of the area are $544.2 \mathrm{~mm}$ and $16.8^{\circ} \mathrm{C}$ respectively. In the Gediz Delta region, which includes the study area, there are four lagoons: Homa (1800 ha), Çilazmak (725 ha), Tas (500 ha) and Kırdeniz (450 ha). Homa Lagoon (38॰ 33', 10" N, 260 49', 50", E) is located $25 \mathrm{~km}$ northwest of the Gulf of Izmir and bordered by the town of Menemen (Fig. 1). Located adjacent to Çamaltı Saltpan and Izmir Bird Sancturay, the lagoon has a surface area of 1800 hectares (ha) and its depth ranges between 0.5 and 1.5 meter. Homa lagoon is one of the most important lagoons on the Aegean coast of Turkey, being a biodiversity hotspot. Because of its enormous species diversity and natural habitats, the lagoon was included in the important wetlands list in the Ramsar Convention.

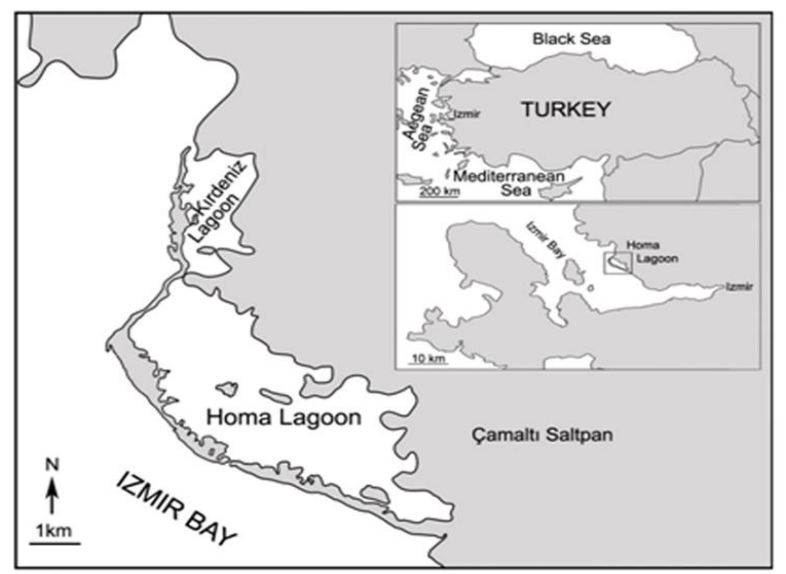

Figure 1. Map of the research area (Homa Lagoon, Turkey)

Periphyton sampling included epipelic algae, epiphytic algae, and epilithic algae. Epipelic diatom samples were taken by using cylindric plexiglas corers $(13 \mathrm{~cm}$ long $\times 6.1 \mathrm{~cm}$ i.d.). The sediment corers were left undisturbed for $24 \mathrm{~h}$. During the exposure period, the corers were artificially illuminated for $2 \mathrm{~h}$. After the waiting period, the sample from the upper part of 0-2 $\mathrm{cm}$ was taken and transferred to $250 \mathrm{ml}$ polythene bottles containing distilled water (Ribeiro et al., 2003). For the collection of epiphytic diatom samples, the macroalgae Ulva lactuca Linnaeus was chosen in the research region. Specimens of Ulva lactuca were placed in a large 1 l sample container until it was about half full and $100-200 \mathrm{ml}$ of distilled water was added. After that, the sealed container was shaken vigorously for ca. 60 seconds. The substrate was then brushed gently to remove the remaining attached diatoms and the suspension was decanted in a $250 \mathrm{ml}$ bottle (Aligizaki and Nikolaidis, 2006). For the identification of epilithic diatoms, stones sized between $15-20 \mathrm{~cm}$ in diameter were collected. The stones were chosen as randomly as possible. From them, only those that were not smoothered with filamentous algae and had an obvious diatom film were taken into consideration. The selected stones were placed in a plastic bath of 1 l filled with $200 \mathrm{ml}$ of distilled water. The upper parts of the stones were brushed with a hard toothbrush and finally the mixture was decanted into the $250 \mathrm{ml}$ polythene bottles (Winter and Duthie, 2000). Finally, all bottles containing epipelic, epiphytic and epilithic diatom samples were fixed with formaldehyde solution (4\% final concentration). Permanent slides for the identification of diatoms were prepared from the same sample. The cleaning of the diatoms involved $10 \% \mathrm{HCl}, 30 \% \mathrm{H}_{2} \mathrm{SO}_{4}$, $\mathrm{KMnO}_{4}$ and oxalic acid (Christiansen, 1988). Cleaned diatoms were mounted permanently on slides with Naphrax and identified at $1000 \times$ magnification by means of phase-contrast optics with OLYMPUS × 100 Plan-apochromatic oil immersion objectives. Identification at species level was made following descriptions of Witkowski et al. (2000) and Witkowski et al. (2010).

\section{RESULTS AND DISCUSSION}

Fogedia giffeniana (N. Foged) Witkowski, Lange-Bertalot, Metzeltin \& Bafana in Witkowski, Metzeltin, Lange-Bertalot \& Bafana 1997

Original publication: Witkowski, A., Metzeltin, D. LangeBertalot, H. \& Bafana, G. (1997). Fogedia gen. nov. (Bacillariophyceae), a new naviculoid genus from the marine littoral. Nova Hedwigia 65: 79-98, 92 figs, 2 tables.

\section{Basionym: Navicula giffeniana Foged}

Homotypic Synonym: Navicula giffeniana Foged 1975

Description: Valves broadly lanceolate with slightly protracted apices, 22.45 to $27.20 \mu \mathrm{m}$ long, 8.35 to $9.55 \mu \mathrm{m}$ wide (Fig. 2).
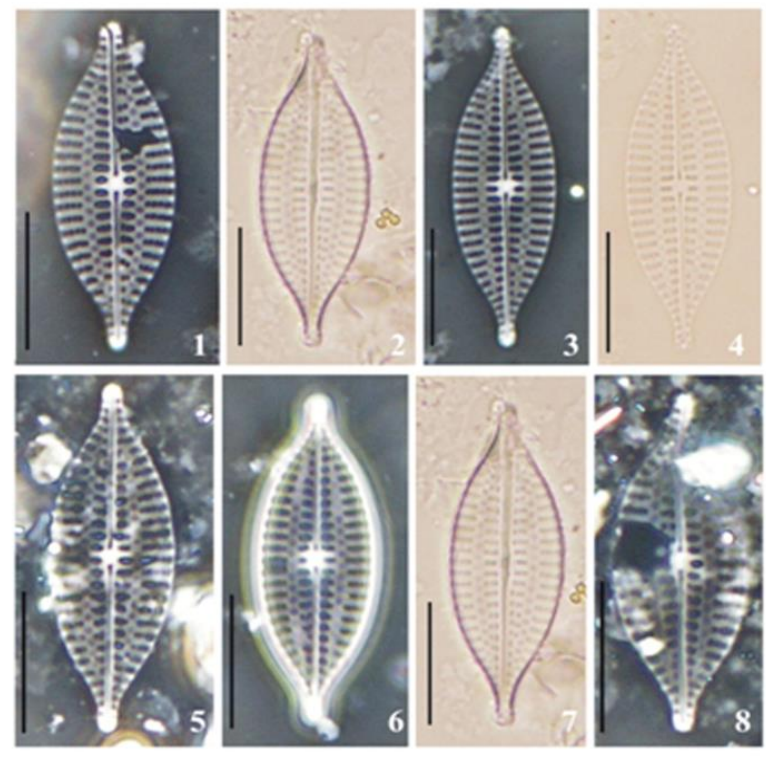

Figure 2. Micrographs of Fogedia giffeniana showing valve view. Scale bar = $10 \mu \mathrm{m}$. 
The transapical striae (11-12 in $10 \mu \mathrm{m})$ vary from parallel in the valve centre to strongly radiate at apices. Morphometric data determined for $F$. giffeniana, especially valve length and striae density (number of transapical striae in $10 \mu \mathrm{m}$ ) showed differences with Witkowski et al. (2000). The valve length for $F$. giffeniana was smaller in our samples than that reported by Witkowski et al. (2000) (26-37 um long). Likewise, the stria density for this species in our samples was less in comparison to that given by Witkowski et al. (2000) (12-14 in $10 \mu \mathrm{m})$.

Ecology and Distribution: Fogedia giffeniana was found only in epipelic and epiphytic diatom assemblages. It has not been reported from epilithic samples so far. When the distributions of this species according to the stations were examined, $F$. giffeniana occurred only at stations 1 and 2 . The station 1 is the deepest station and throughout the sampling period the water depth is approximately $1.5 \mathrm{~m}$. The station is exposed to the wave action and the sea floor is covered with gravel and sand. The station 2 is located in the region where the sea water is mixing with the lagoon water. This station is a little more sheltered than station 1 and has soft sediment substrate. Station 3 and 4 are less affected by sea water in comparison to the other stations and this species has not been reported there. This species originates from warm waters (Witkowski et al., 2010). It has been reported thus far from the western Indian Ocean (Oman, Yemen, Kenya) and from the Mediterranean Sea (Witkowski et al., 2000; Witkowski, A. unpubl.).

Fogedia giffeniana from Bacillariophyceae were reported for the first time from Turkish coastal waters. The species identified in this study is relatively uncommon species. Similarly, there have been no records of the genus Fogedia predominance in diatom assemblages in the entire world, only except in F. geisslerae, which was found in the North Sea at $\mathrm{Rm}$ Island, Denmark (Witkowski, unpubl). So far, eight

\section{REFERENCES}

Aligizaki, K., Nikolaidis, G., 2006. The presence of the potentially toxic genera Ostreopsis and Coolia (Dinophyceae) in the North Aegean Sea, Greece. Harmful Algae, 5: 717-730. doi: 10.1016/j.hal.2006.02.005.

Christiansen, T., 1988. Alger I naturen og I laboratoriet. Nørregade, Denmark: Københavns Universitets Institut for sporeplanter, $137 \mathrm{pp}$.

Cirik, S., Alpbaz, A., Gökpınar, Ş., Metin, C., 1991. A study on phytoplankton of Homa (Süyo) Lagoon (Izmir bay). E.Ü. Faculty of Fisheries, Fisheries Symposium in the 10th year of education, Izmir. 590-600.

Cleve, P. T., and Grunow, A., 1880. Beiträge zur kenntniss der arctischen Diatomeen. Kongliga Svenska vetenskaps-akademiens handlingar, 17 1-121.

Cox, E.J., 1979. Studies on the diatom genus Navicula Bory. The typification of the genus. Bacillaria, 2: 137-153.

Çolak Sabancı, F., Koray, T., 2010. Four new records for the benthic diatoms (genera Cocconeis, Seminavis, Synedra, and Trachysphenia) from the Aegean Sea. Turkish Journal of Botany, 34(6): 531-540. doi:10.3906/bot-0912-285. species belonging to genus Fogedia were recorded and presently twelve Fogedia species are known (Park et al., 2013). Focusing on the worldwide distribution of species of the genus Fogedia examined, they found that (I) F. acuta England (Salah, 1955), Oregan (Witkowski et al., 2000); (II) F. christensenii Fiji (Witkowski et al., 1997); (III) F. coreana Korea (Park et al., 2013); (IV) F. densa China (Park et al., 2013), Korea (Park et al., 2013); (V) F. elliptica China (Park et al., 2013), Korea (Park et al., 2013); (VI) F. finmarchia Norway (Cleve and Grunow, 1880), England (Salah, 1955), Chile (Rivera, 1968), Greenland (Foged, 1973), Canary Islands (van den Heuvel and Prud'homme van Reine, 1985), Greek Island of Kos and Kalymnos (Foged, 1985), Fiji (Foged, 1987), Baltic Sea (Witkowski, 1994), North Croatia (Galović and Bajraktarević, 2006), Korea (Joh, 2013); (VII) F. geisslerae Baltic Sea (Witkowski, 1994); Wadden Sea (Witkowski et al., 1997); (VIII) F. giffeniana Tanzania (Foged, 1975), Fiji (Foged, 1987), Oman (Witkowski et al., 1997), Korea (Joh, 2013); (IX) F. giffeniana var. yementica Yemen (Witkowski et al., 1997); (X) F. heterovalvata Baltic Sea (Simonsen, 1959), Caribbean Sea (Witkowski et al., 2000), Korea (Joh, 2013); (XI) F. krammeri California (Witkowski et al., 2010), Korea (Joh, 2013); (XII) F. lyra Korea (Park et al., 2013), Japan (Park et al., 2013). While the species have been reported to inhabit many different places of the world, a majority of the recorded taxa were the only member of the genus found in one location studied. A genus Fogedia is distributed in tropical regions (Witkowski et al., 1997), temperate zone (Witkowski et al., 2000), cold water (Witkowski et al., 2010), however, rarely in the polar seas (Hendey, 1964; Witkowski et al., 2000). The occurrence of this species for the first time in this study may be related to the lack of adequate studies in this region. In addition, there is generally less scientific expertise and research conducted on benthic diatoms compared with corresponding studies in phytoplankton.

Çolak Sabancı, F., 2011. Relationship of epilithic diatom communities to environmental variables in Homa lagoon (Izmir, Turkey). Aquatic Biology, 13: 233-241. doi: $10.3354 / a b 00367$

Çolak Sabancı, F., 2012a. An Illustrated Survey On The Morphological Characters In Three Species Of The Diatom Genus Mastogloia (Bacillariophyceae). Turkish Journal of Botany, 36 (6): 727-737. doi: 10.3906/bot-1111-18.

Çolak Sabancı, F., 2012b. Taxonomic Survey Of Benthic Diatoms On Natural Substrata From Coastal Lagoon (Aegean Sea, Turkey). Turkish Journal of Fisheries and Aquatic Sciences, 12(4): 841-849. doi:10.4194/1303-2712-v12_4_12

Çolak Sabancı, F., 2013. Species of Mastogloia (Bacillariophyceae) new for the Aegean coast of Turkey. Mediterranean Marine Science, 14 (1): 129140. doi:10.12681/mms.331.

Foged, N., 1973. Diatoms from southwest Greenland. Meddelelser om Grnland 194: 1-84.

Foged, N., 1975. Some littoral diatoms from the coast of Tanzania. Bibliotheca Phycologica, 16: 1-128. 
Foged, N., 1985. Diatoms in Kos and Kalymnos, two Greek islands in the Aegean. Bibliotheca Diatomologica, 10: 1-104.

Foged, N., 1987. Diatoms from Viti Levu, Fiji Islands. Biblotheca Diatomologica 14: 1-128.

Galović, I., and Bajraktarević, Z., 2006. Sarmatian biostratigraphy of the Mountain Medvednica at Zagreb based on siliceous microfossils (North Croatia, Central Paratethys). Geologica Carpathica, 57 (3). 199-210.

Hendey, N. I., 1964. An introductory account of the smaller algae of British coastal waters. Part V: Bacillariophyceae (Diatoms). Fishery Investigations, Series IV. Her Majesty's Stationery Office, London, 317 pp.

Joh, G., 2013. Species diversity of the old genus Navicula Bory (Bacillariophyta) on intertidal sand-flats in the Nakdong River estuary, Korea. Journal of Ecology and Environment, 36(4): 371-390.

Lange-Bertalot, H., 2001. Navicula sensu stricto, 10 genera separated from Navicula sensu lato, Frustulia. Diatoms of Europe 2: 1-526.

Park, J., Khim, J. S., Ryu, J., Koh, C. H., Witkowski, A., 2013. An emended description of the genus Fogedia (Bacillariophyceae) with reports of four species new to science from a Korean sand flat. Phycologia, 52 (5): 437446.

Ribeiro, L., Brotas, V., Mascarell, G., Couté, A., 2003. Taxonomic survey of the microphytobenthic communities of two Tagus estuary mudflats. Acta Oecologica, 24: 117-123. doi: 10.1016/S1146-609X(03)00012-2

Rivera, P. R., 1968. Sinopsis de las diatomeas de la Bahia De Comception. Gayana Botanica 18: 1-11.
Round, F. E., Crawford, R. M., Mann, D. G., 1990. The diatoms. Biology and morphology of the genera. Cambridge, England: Cambridge University Press, $760 \mathrm{pp}$.

Salah, M. M., 1955. Some new diatoms from Blakeney Point (Norfolk). Hydrobiologia, 7: 88-102.

Simonsen, R., 1959. Neue Diatomeen aus der Ostsee. I. Kieler Meeresforschungen, 15: 74-83.

Van Den Heuvel, H. M. and Prud' Homme Van Reine, W. F., 1985. Marine, mainly benthic diatoms of the west coast of the Island La Palma (Canary Islands). Vieraea, 14: 11-31.

Winter, J. G., Duthie, H. C., 2000. Stream epilithic, epipelic and epiphytic diatoms: habitat fidelity and use in biomonitoring. Aquatic Ecology, 34: 345-353.

Witkowski, A., 1994. Recent and fossil diatom flora of the Gulf of Gdansk, Southern Baltic Sea. Biblotheca Diatomologica, 28: 1-313.

Witkowski, A., Metzeltin, D., Lange-Bertalot, H., Bafana, G., 1997. Fogedia gen. nov. (Bacillariophyceae), a new naviculoid genus from the marine littoral. Nova Hedwigia, 65(1-4): 79-98.

Witkowski, A., Lange-Bertalot, H., Metzeltin, D., 2000. Diatom flora of Marine Coasts I. Iconographia Diatomologica 7: 1-925.

Witkowski, A., Lange-Bertalot, H., Kociolek, J. P., Kulikovskiy, M., Bak, M., Ruppel, M., 2010. Diatom flora of San Francisco Bay and vicinity. II. Fogedia krammeri sp. nov. Polish Botanical Journal, 55(1): 49-53. 